$\xi=-1$

\title{
Current Issues of Economic Security of the Eurasian Economic Union
}

\author{
Valentina Danilovna Kovaleva ${ }^{1}$, Mikhail Gennadevich Rusetskiy ${ }^{2}$, Zhanna Alexandrovna Shadrina ${ }^{3}$, Gayane Agop- \\ ovna Kochyan $^{4}$, Larisa Stanislavovna Zarovnaya ${ }^{5}$
}

1Stavropol Institute of Cooperation (Branch) Belgorod University of Cooperation, Economics and Law

Goleneva Street, 36, Stavropol, 355000, Russian Federation

2North Caucasus Federal University (NCFU)

Pushkina St., 1, Stavropol, 355009, Russian Federation

3Kuban State Technological University (KubSTU)

Moskovskaya St., 2, Krasnodar, 350072, Russian Federation

4Kuban State Technological University (KubSTU)

Moskovskaya St., 2, Krasnodar, 350072, Russian Federation

5 Kuban State Technological University (KubSTU)

Moskovskaya St., 2, Krasnodar, 350072, Russian Federation

\begin{abstract}
The article considers the main aspects that characterize the economic security system of the Eurasian Economic Union (EAEU) and means to ensure economic security that contribute to increasing economic potential and to creating conditions for the effective development of integration processes. The authors investigated the main documents of the Eurasian Economic Commission (EEC), a constantly acting regulating body of the EAEU, and developed recommendations for creating unified strategies of the economic security of the Eurasian Economic Union that can be implemented in the system of risk management that, in turn, is based on the controlling toolkit. In the process of the research it was determined that the political aspect alone is not enough for the preservation and effective development of the Eurasian Economic Union as common economic interests and possible effects from their implementation are the crucial components of viability of any integration union including the EAEU country members. In this regard the formation of the system of economic security of the integration union of Russia, Belarus, Kazakhstan, Armenia and Kyrgyzstan is a relevant issue. In order to contribute to the integration of the countries of the Eurasian Economic Union that is based on the geopolitical aspect it is necessary to ensure economic security which determines both the theoretical and practical significance of the study. At the same time such integration would promote the unification of the EAEU countries that are different in the level of their socio-economic development.
\end{abstract}

Keywords: economic security, economic security system, state, economy, the Eurasian Economic Union, the EAEU, the Eurasian Economic Commission, the EEC, integration processes, economic potential, controlling, economic indicators, monitoring.

\section{Introduction}

In the conditions of the formation and development of market economy integration processes are at the basis of the effective development of every country. In accordance with the conception of Russian and foreign scientists, the key idea which underpins integration processes consists in the appropriateness for those countries that are characterized by the equal level of economic development. In this regard the integration processes are characterized in an economic aspect reflecting the aggregate financial result that is based on uniting economic potentials of each country. However, after the collapse of the Soviet Union the geopolitical factor affected the integration processes; the essence of this geopolitical factor consists in the fact that the formation of any integration, including the European Union and the Eurasian Economic Union, broadens the spheres of their influence at the expense of less developed countries [8]. It is evident that this factor aggravated the problem of economic security of integration of the postSoviet countries $[1,6]$. In this regard the relevant problem includes the provision of economic security of every integration union, including the Eurasian Economic Union, basing on ensuring national and economic security for every member country $[14$, 15].

The system of economic security of the EAEU is necessary for the formation of the trajectory of the effective development of the Common Economic Space (CES) within which the Eurasian Economic Union (EAEU) has been functioning since 2015 including Russia, Belarus, Kazakhstan, Armenia and Kyrgyzstan [19]. The creation of the Eurasian Economic Union involves comprehensive modernization, cooperation, increase in competitiveness of national economies and establishment of conditions contributing to stable socio-economic development of the EAEU countries in the interest of improving living standards of the population [10].

\section{Methodology}

The methodological basis of the research included dialectal approach to the cognition of phenomena and patterns of the system of economic security to optimize the integration processes. The research is based on the theory and methods related in the funda- 
mental works off Russian and foreign scientists on the problems of economic security [9]. In our opinion, that does not contradict the conception developed by the Organisation for Economic Cooperation and Development (OECD - an international interstate Organisation of economically developed countries that acknowledge principles of representative democracy and free market economy); the main essence of the strategy of economic security is the economic policy of member countries [13]. The unified economic policy of the Eurasian economic space must integrate the elements of economic security of each EAEU country $[2,5,18]$. It is evident that such a strategy of the EAEU will ensure the formation of an effective system both in the Eurasian Economic Union and in every participant country as well as the economic effect that exceeds the one that was achieved by each country separately.

The Eurasian Economic Commission established on 2 February 2012 is the constantly acting regulating body of the Eurasian Economic Union. Its main aims are to provide the conditions for the functioning and developing if the EAEU, to develop proposals for further development of the integration in accordance with the strategy contributing to economic security [11].

The application of theoretic approaches and conceptions to economic integration in combination with the principles of social and cause-and-effect approaches enabled to investigate the problem of economic security at a sufficiently high scientific level.

The methodology of system analysis is implemented in the research, which included the use of a set of general scientific methods (system, complex, dialectic, induction and deduction, analysis and synthesis) as well as methods of morphological analysis (management by objectives), logical modelling.

\section{Results}

Practical recommendations that contribute to the formation and development of the system of economic security of the EAEU countries are suggested. In the course of the research the main factors affecting economic security of the EAEU countries were defined. It was also found out that one of the major objectives of the Eurasian Economic Commission includes the adjustment of the effective mechanism of information exchange that characterizes direct and indirect threats to economic security of the Eurasian Economic Union. Relevant information on the state of the system of economic security of the EAEU countries and the Eurasian Economic Union in general is generated through the controlling toolkit and is the foundation for the development of an affective system of economic security [7].

As a result of the research of systems of national economic security of the EAEU countries an initial position to create a toolkit that enables to integrate the elements of the strategy of economic security for each country of the Eurasian Economic Union was defined. It also contributes to regulating the system of economic security of at the level of the EEC authority basing on the modelling presenting a systematized means to objectively compare alternative solutions (Figure 1). The evaluation of the state of economic security of the EAEU is based on the timely detection of challenges and threats for economic security of each participant country, on the rapid response to them, on developing management decisions and recommendations formed by the risk management system within the controlling toolkit.

The main goals of risk management include:

1) identifying and assessing current and potential challenges and threats for economic security of the EAEU countries;

2) assessing resources necessary and sufficient for preventing challenges and threats for economic security of the EAEU countries;
3) planning state policy in the sphere of providing economic security for each EAEU country, defining objectives of executive bodies, subjects of natural monopolies, government corporations, companies and other concerned organizations;

4) developing management decisions aimed at opposing economic sanctions imposed on the EAEU countries, monitoring of their implementation and the effectiveness assessment as well as providing responses against countries that impose the given sanctions.

In order to agree on the trajectory of the development of the EAEU countries the quantitative and qualitative aspects characterizing the condition of economic security of the given countries are presented. To objectively assess the systems of economic security, to single out the tendencies to optimizing maim factors and, thus, to reduce threats to economic security of the EAEU countries we have studied the data of the analytical report of the Word Bank "Doing Business 2017", XVI edition of "Doing Business" project that is published by the World Bank and International Finance Corporation (a part of the World Bank group). In the analytical report a ranking of 189 countries is presented according to an indicator of creating favorable conditions for conducting business in which quantitative and qualitative aspect characterizing the main components of the systems of economic security of 190 countries [3].

In the course of the conducted research we managed to identify the general problems affecting the condition of the system of economic security of the EAEU and national systems of economic security of the EAEU participant countries; these issues influence negatively the activity of mutually profitable trade relations. Uneven distribution of tax burden of economic subjects of the EAEU countries and differences in legislation base influence directly or indirectly the condition of the socio-economic development, the durability of economic potential of each EAEU country and their capacity to resist both current and potential challenges and threats to their economic security [17].

For instance, the complete unification of the basic tax rates in the EAEU member countries was not achieved, since the amount of tax rates and fees depends on the level of the economic development of each country, on the conducted tax policy and on the implementation of reforms in the given sphere. The Consultative Commission for Tax Policy and Administration of the EEC is advisable to consider the opportunities of implementing the experience of the European Union in the Eurasian Economic union; in the EU, according to the project of the directive on the general European system of value added tax, it is planned to establish the minimally acceptable VAT rate for five subsequent years [4].

\section{Discussion}

In order to draw up a ranking ten indicators are used. They have equal significance, underlie the process of regulating entrepreneurship activity, take into account the time and cost of meeting the requirements of the country for registering new enterprise by the entrepreneur, enable to conduct trade operations, provide contract fulfillment, taxation and closure of enterprise. In the process of drawing up a ranking of a country such variables as macroeconomic policy, infrastructure quality, qualification of labour force, currency fluctuations, investors' opinions, security and the level of corruption are taken into account. Consequently, the conditions of organizing and conducting business in each country are considered exclusively at the level of state regulation, without taking into account political aspects. The final ranking reflects the rank of each country the value of which is determined by the level of favorable conditions for conducting business, where a high position means that its regulation climate contributes to conducting business and characterizes economic security [3]. 


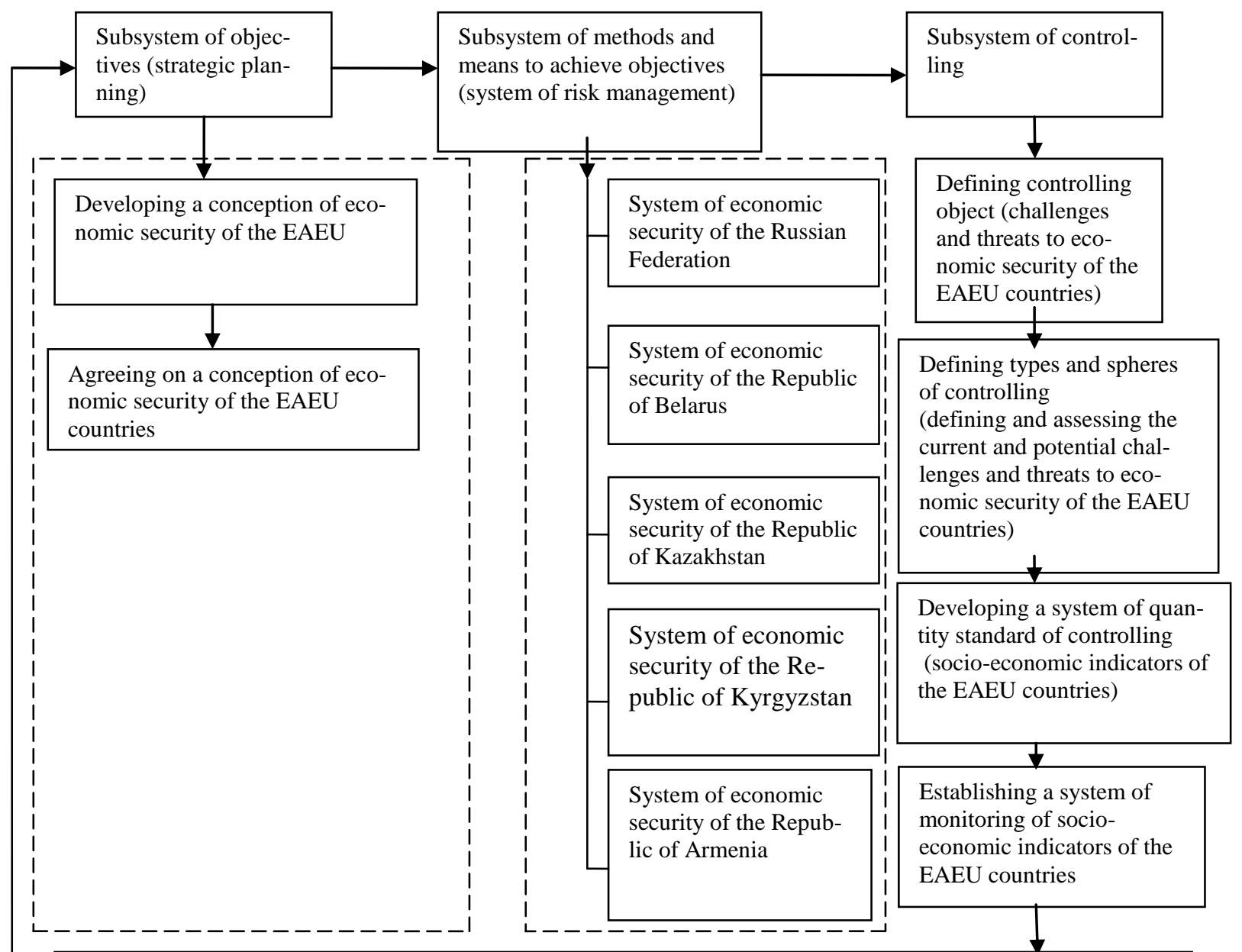

Establishing a system of information accounting data (primary information base of observation)

Calculating analytical indicators and defining methods of analysis

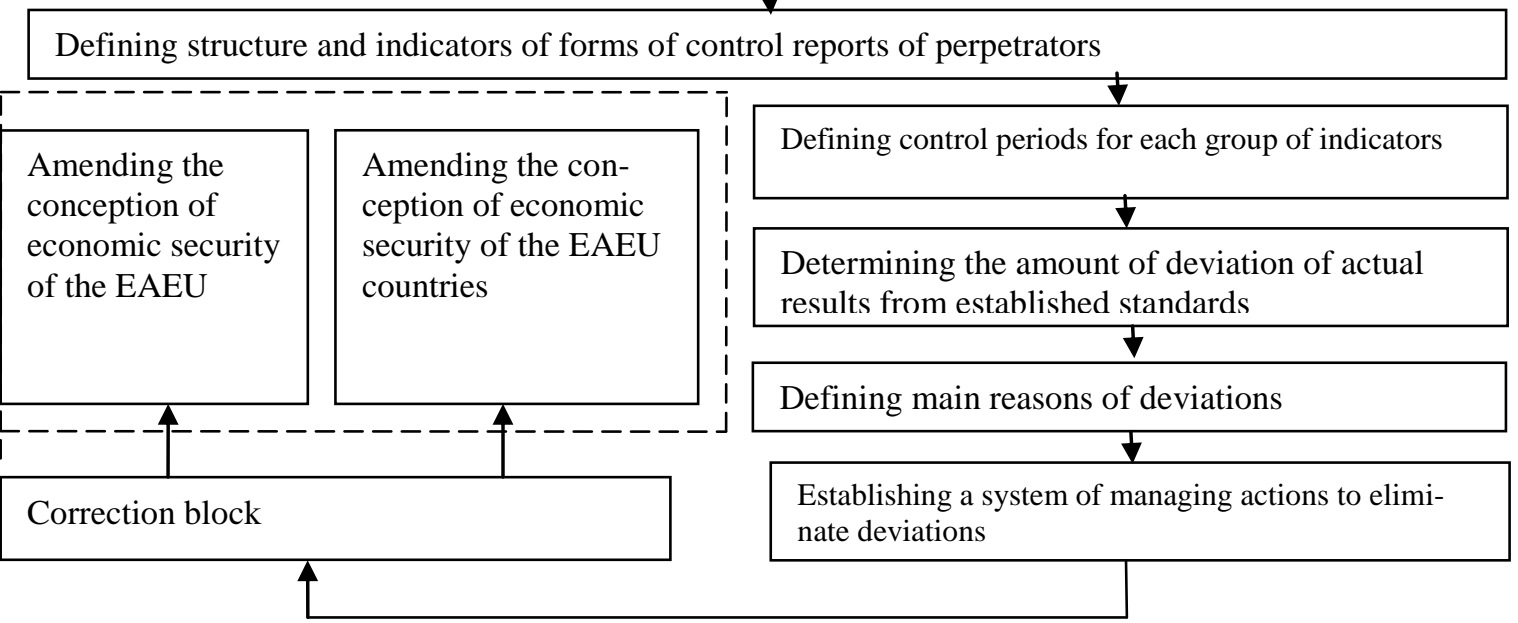

Fig. 1. Model of forming a system economic security of the EAEU countries

In order to draw up the image of economic security of the EAEU countries we have carried out the analysis of the research results of the analytical report of the World Bank "Doing Business 2017" that was conducted from June 2015 to June 2016. The results of the conducted research demonstrated that during the given period experts recorded 283 normative legal reforms in the sphere of regulating entrepreneurship activity in 137 countries that are aimed at improving conditions for establishing and conductin business and, consequently, for economic security. The most significant reforms included the ones that sought to simplify the procedure of establishing an enterprise, that were conducted in the sphere of taxation and the ones that contributed to accessing to loans and regulating international trade.

The key parameters considered as criteria underlying the assessment of the system of economic security of the EAEU countries are presented in Table 1. 
Table 1. Criteria for assessing the system of economic security of the EAEU countries

\begin{tabular}{|c|c|c|c|c|c|}
\hline Name of a factor affecting economic security & Armenia & Belarus & Kazakhstan & Kyrgyzstan & Russia \\
\hline Registration of enterprises & 9 & 31 & 45 & 30 & 26 \\
\hline Obtaining permission for building & 81 & 28 & 22 & 32 & 115 \\
\hline Connecting to the electricity system & 76 & 24 & 75 & 163 & 30 \\
\hline Registration of property & 13 & 5 & 18 & 8 & 9 \\
\hline Lending & 20 & 101 & 75 & 32 & 44 \\
\hline Protection of investors & 53 & 42 & 3 & 42 & 53 \\
\hline Taxation & 88 & 99 & 60 & 148 & 45 \\
\hline International trade & 48 & 30 & 119 & 79 & 140 \\
\hline Providing contracts fulfillment & 28 & 27 & 9 & 141 & 12 \\
\hline Liquidation of enterprises & 78 & 69 & 37 & 130 & 51 \\
\hline Ranking & 38 & 37 & 35 & 75 & 40 \\
\hline
\end{tabular}

As a result of data analysis presented in Table 1 it was defined that Kazakhstan and Belarus offer the most favorable conditions for registering an enterprise during the given period in the EAEU. It confirms the fact that the reforms, aimed at improving entrepreneurship environment and economic security in these countries, were successful.

Despite the significant improvements in the condition of economic security, the given countries still have problems that require solution. In this regard the main direction of forming and developing the system of economic security of the Eurasian Economic Union includes its transformation into an effective instrument of market economy that is capable of solving socio-economic objectives in each particular country [20].

To achieve this aim is possible only on the condition of implementing the strategy of economic security in the system of risk management that is based on the controlling toolkit. In this regard the vector of strategic development of Russia, Belarus, Kazakhstan, Armenia and Kyrgyzstan must be oriented towards:

increasing competitiveness of economic subjects of these countries;

eliminating barriers, excluding disproportions affecting the development of economic ties;

creating equal conditions for economic subjects;

balancing national legislations, providing their openness, transparency, understandability and stability [16].

Determining the vector of strategic development of economic security of the Eurasian Economic Union in the system of risk management that is based on the controlling toolkit is due to the necessity to create favorable conditions for socio-economic development of each EAEU country.

\section{Conclusion}

In the course of the research we managed to determine that economic security within the market economy is a key factor characterizing favorable conditions for organizing and conducting business. In this regard, for the effective development of the Eurasian Economic Union countries, a conception of economic security contributing to implementing the strategic vector in the system of risk management basing on the controlling toolkit which takes into account the specifics of national systems of economic security of the Russian Federation, Belarus, Kazakhstan, Armenia and Kyrgyzstan is necessary. The functions and power to carry out monitoring and assessing the condition of economic security are given to the legislative and executive authorities of the Eurasian Economic Union that perform functions of promoting state policy and normative-legal regulation in the sphere of analysis and predicting socio-economic development of the EAEU.

Developing the conception of economic security of the Eurasian Economic Union contributes to stimulating competitiveness, thus, creating the most favorable conditions for accumulating capital and providing the functioning of internal market

with minimal restrictions and barriers. The effective strategic planning of economic security enables to implement one of the dom of the movement of goods, services, capital and labour force on the territory of the Eurasian Economic Union.

\subsection{Conflict of Interest}

The authors confirm that the data do not contain any conflict of interest.

\section{References}

[1] L.I. Abalkin. Economic Security of Russia. Bulletin of RAS, 9, 1997.

[2] Decree of the President of the Republic of Belarus № 575. Conception of national security of the Republic of Belarus. November 9, 2010

[3] Doing Business. 2018. Available online: http://www.doingbusiness.org/

[4] European Union Draft Directive on Value Added Tax. Available online: https://ec.europa.eu/commission/index_en

[5] Federal Law № 390-FL. On Security. December 28, 2010.

[6] S.Yu. Glazyev. The basis for providing economic security in Russian alternative reformation course. Russian Economic Journal, 1, 1997.

[7] V.D. Kovaleva. The formation of the controlling system in the conditions of establishing and developing of innovative economy. Economics and Management: Problems and Solutions. Scientific Practical Journal, 2(38), 2016, pp. 180-183.

[8] V.D. Kovaleva. The problems and perspectives of the Eurasian economic integration. Proceedings of the International On-line Conference on the base on Communication Ground "G-global". Accounting, Audit and Analysis: International Practice, tendencies and development perspectives: Astana. L.N. Gummily Eurasian National University, 2017, pp. 488-492.

[9] Laffer, A.B., Seymour, J.P. The Economics of the Tax Revolt. New York: Harcourt Brace Jovanovich, 1979.

[10] Official website of the EAEU. Available online: http://www.eaeunion.org/

[11] Official website of the Eurasian Economic Commission. Available online: http://www.eurasiancommission.org/

[12] Official website of the Eurasian Economic Commission. Available online:

http://www.eurasiancommission.org/ru/act/integr_i_makroec/dep_stat/D ocuments/Foundations\%20of\%20statistics.pdf

[13] Official website of the Organisation for Economic Cooperation and Development, OECD. Available online: http://www.oecd.org/

[14] On the strategy of economic security of the Russian Federation for the period up to 2030: Decree of the President of the Russian Federation № 208. May 13, 2017.

[15] On the strategy of national security of the Russian Federation for the period up to 2030: Decree of the President of the Russian Federation № 683. December 31, 2015.

[16] Protocol. On Electronic Form of Information Exchange between Tax Authorities of the Eurasian Economic Union Countries on Paid Indirect Taxes. December 11, 2009 (ed. December 31, 2014). Available online: http://www.consultant.ru/document/cons doc LAW_102837/

[17] The department of the development of entrepreneurship activity. Available online: http://www.eurasiancommission.org/ru/act/finpol/dobd/Pages/default.as $\mathrm{px}$

[18] The Law of the Republic of Kazakhstan № 233-I. National Security of the Republic of Kazakhstanю June 26, 1998.

[19] The united economic space (UES). Reference. Available online: https://ria.ru/spravka/20120101/529308191.html

[20] Treaty. On the Eurasian Economic Union. Astana. May 29, 2014. In force since August 12, 2017. Available online: http://www.consultant.ru/document/cons_doc_LAW_163855/ 